\title{
Common fibroid-associated genes are differentially expressed in phenotypically dissimilar cell populations isolated from within human fibroids and myometrium
}

\author{
Sarah J Holdsworth-Carson*, Marina Zaitseva ${ }^{*}$, Jane E Girling, Beverley J Vollenhoven \\ and Peter A W Rogers
}

Department of Obstetrics and Gynaecology, Gynaecology Research Centre, Royal Women's Hospital, University of Melbourne, Level 7, 20 Flemington Road, Parkville, Victoria 3052, Australia and ${ }^{1}$ Department of Obstetrics and Gynaecology, Monash University, Clayton, Victoria, Australia

Correspondence should be addressed to PAW Rogers; Email: parogers@unimelb.edu.au

${ }^{*} \mathrm{~S} J$ Holdsworth-Carson and M Zaitseva consider that the first two authors should be regarded as joint first authors

\begin{abstract}
Uterine fibroids are a prevalent gynaecological condition in reproductive-aged women and are the commonest reason for hysterectomy. The cellular composition of clonal fibroids are heterogeneous, with phenotypically dissimilar cells that include smooth muscle cells (SMC), vascular SMC (VSMC) and fibroblasts. The aim of our study was to investigate genes that are commonly differentially expressed between fibroid and myometrial whole tissues in phenotypically different sub-populations of cells isolated from fibroid and myometrium. Genes to be investigated by fluorescence-activated cell sorting, quantitative real-time PCR and immunocytochemistry include transforming growth factor $\beta$ (TGFB) and retinoic acid (RA) signalling families and steroid hormone receptors. We hypothesised that each cell population isolated from fibroid and myometrium would differ in the expression of fibroid-associated genes. We demonstrated that phenotypically different cellular constituents of uterine fibroids differentially express cellular RA-binding protein 2 (CRABP2), progesterone receptor $B(P R B)$ and TGFB receptor 2 mRNA in fibroid-derived cells of VSMC and SMC phenotype. CRABP2 mRNA was also differentially expressed in fibroblasts and VSMC sub-populations from within clonal fibroid tumours. We conclude that differential regulation of RA, TGFB and PR pathway transcription occurs in fibroid-associated SMC and -fibroblasts and that investigation of paracrine interactions between different cell types within the fibroid microenvironment provides an important new paradigm for understanding the pathophysiology of this common disease.

Reproduction (2014) 147 683-692
\end{abstract}

\section{Introduction}

Uterine fibroids are benign tumours of the myometrium and are a prevalent gynaecological condition in reproductive-aged women (reviewed by Rice et al. (2012)). In Australia and globally, the commonest reason for hysterectomy is fibroids (Treloar et al. 1999, Rice et al. 2012). In the USA, uterine fibroids pose a significant cost to society, with annual direct and indirect healthcare costs estimated at up to US\$34.4 billion (Cardozo et al. 2012). In spite of the high incidence, substantial health problems and significant economic burden, a lot remains to be learnt about the origins and pathogenesis of uterine fibroids.

In the vast majority of published studies, uterine fibroids are considered to be composed of entirely smooth muscle cells (SMC). Others and we have shown that in addition to SMC, phenotypically dissimilar cells make up a major component of uterine fibroids, including vascular SMC (VSMC) and fibroblasts (Koumas et al. 2001, Zaitseva et al. 2007, Moore et al. 2010, Holdsworth-Carson et al. 2014). It is known that the tumour microenvironment greatly impacts on tumour growth and is strongly influenced by paracrine signalling between several different interacting cells and their secretomes; critical in this process are fibroblasts (Elenbaas \& Weinberg 2001). Members of the transforming growth factor $\beta$ (TGFB) family participate in tumour microenvironment signalling, playing a major role in fibroblast-associated tumorigenesis. Members of the TGFB family can elicit tumour-promoting effects in a paracrine manner by triggering fibroblast differentiation and desmoplastic responses from neighbouring mesenchymal cells within a tumour (reviewed by Elenbaas \& Weinberg (2001) and Polanska \& Orimo (2013)). Activation of the retinoic acid (RA) pathway significantly reduces growth and extracellular matrix composition of uterine fibroid cells via regulation of the TGFB pathway (Malik et al. 2008). In fibroblasts, 
differential regulation can occur via the RA receptors (RAR), which are cell-type specific with distinctive receptor binding properties between different cell types (Delacroix et al. 2010), providing a mechanism for paracrine interaction in the tumour microenvironment. Uterine fibroids are hormonally regulated, as are cancerous tumours of the breast. Interactions between different cell types (fibroblasts and tumour cells) within breast tissues underlie oestrogen- and progesteronedependent mechanisms of tumour cell proliferation (Haslam \& Woodward 2003, Chottanapund et al. 2013). Therefore, the relationship and paracrine signalling between heterogeneous cells of uterine fibroids warrants consideration as a possible mechanism underlying fibroid progression, with particular attention paid to steroid hormone receptors, TGFB and RA pathways.

Despite recent evidence demonstrating cellular heterogeneity in uterine fibroids, these tumours are clonal (Holdsworth-Carson et al. 2014). Uterine fibroids are amplified from a single progenitor cell that differentiates into phenotypically different cells which in many ways mimic the surrounding myometrium. Previous comparisons of differential gene expression between fibroid and normal myometrium have been performed on heterogeneous cell populations from whole tissue or mixed cell cultures. While such investigations have uncovered significant pathways that distinguish fibroid from myometrium, the phenotypic heterogeneity of cells within the fibroid is not taken into consideration.

Studies describing differential gene expression between fibroid and myometrial whole tissues have repeatedly identified overlapping gene pathways that are abnormally expressed in fibroids, including genes important to the paracrine mechanisms within the local tumour microenvironment. Of relevance to this investigation, it is interesting to note that genes associated with steroid hormone regulation, the TGFB pathway and genes involved in the RA pathway make up a significant portion of genes that are differentially expressed in fibroid tissue compared with myometrium (refer to Table 1 for a brief summary; Sadan et al. 1987, Dou et al. 1996, Tsibris et al. 2002, Skubitz \& Skubitz 2003, Weston et al. 2003, Shozu et al. 2004, Arslan et al. 2005, Leppert et al. 2006, Zaitseva et al. 2006, 2007, Roth et al. 2007, Litovkin et al. 2008, Lee et al. 2010, Moore et al. 2010, Davis et al. 2013, Yin et al. 2013).

The aim of this study was to investigate the genes that are differentially expressed between fibroid and myometrial whole tissues and have known roles in maintaining the tumour microenvironment, in phenotypically different sub-populations of cells isolated from fibroid and myometrium. Genes to be investigated belong to the steroid hormone receptor (oestrogen receptors $(E R \alpha / \beta)$ and progesterone receptors $(\mathrm{PRA} / \mathrm{B}))$, TGFB (TGFB1/3 and TGFB receptors (TGFBR1/2)) and RA signalling families (cellular RA-binding protein 2 (CRABP2)). We hypothesised that each cell population isolated from fibroid and myometrium will differ in the expression of fibroid-associated genes. Study of gene expression in each cellular constituent of fibroids relative to myometrium may provide important new insights into how paracrine interactions between different cell type(s) contribute to fibroid growth and development.

\section{Materials and methods}

\section{Tissue collection}

Paired myometrium and fibroid tissues were collected from women who were undergoing hysterectomy for fibroids $(n=13$, mean age $46.9 \pm 1.1$ years). Ethics approval for this study was obtained from the Royal Women's Hospital Human

Table 1 TGFB, steroid hormone and RA pathway genes differentially expressed in fibroid compared with myometrium tissues.

\begin{tabular}{|c|c|c|c|}
\hline Pathway & Gene name & $\begin{array}{l}\text { Increased/decreased } \\
\text { in fibroid relative to } \\
\text { myometrium }\end{array}$ & References \\
\hline $\begin{array}{l}\text { Transforming } \\
\quad \text { growth factor } \beta\end{array}$ & $\begin{array}{l}\text { Transforming growth factor } \beta \text { (TGFB1) } \\
\text { TGFB3 } \\
\text { TGFB receptor } 1 \text { (TGFBR1) } \\
\text { TGFBR2 }\end{array}$ & $\begin{array}{l}\uparrow / \text { no change } \\
\uparrow \\
\uparrow \\
\uparrow / \downarrow\end{array}$ & $\begin{array}{l}\text { Dou et al. (1996), Tsibris et al. (2002), Leppert et al. } \\
\text { (2006), Moore et al. (2010) and Yin et al. (2013) }\end{array}$ \\
\hline Steroid hormone & $\begin{array}{l}\text { Oestrogen receptor } \alpha(E S R 1 \text { or } E R \alpha) \\
\text { Oestrogen receptor } \beta(E S R 2 \text { or } E R \beta) \\
\text { Aromatase } \\
17 b-H y d r o x y s t e r o i d ~ d e h y d r o g e n a s e\end{array}$ & $\begin{array}{l}\uparrow \\
\uparrow \\
\uparrow \\
\uparrow\end{array}$ & $\begin{array}{l}\text { Shozu et al. (2004), Lee et al. (2010) and Yin et al. } \\
\text { (2013) }\end{array}$ \\
\hline & Progesterone receptor (PRG or $P R$ ) & $\uparrow /$ no change & $\begin{array}{l}\text { Sadan et al. (1987), Leppert et al. (2006), Zaitseva } \\
\text { et al. (2006), Lee et al. (2010) and Yin et al. (2013) }\end{array}$ \\
\hline Retinoic acid & $\begin{array}{l}\text { Cellular retinoic acid-binding protein } \\
\quad(C R A B P 1 \text { and } C R A B P 2) \\
\text { Retinol dehydrogenase }(R O D H) \\
\text { Alcohol dehydrogenase } 1(A D H 1) \\
\text { Aldehyde dehydrogenase }(A L D H 1) \\
\text { Cellular retinol-binding proteins (CRBP1 } \\
\text { and } C R B P 2) \\
\text { Retinoid } X \text { receptors ( } R X R \alpha \text { and } R X R \gamma)\end{array}$ & $\begin{array}{l}\uparrow \\
\downarrow \\
\downarrow \\
\downarrow\end{array}$ & $\begin{array}{l}\text { Tsibris et al. (2002), Skubitz \& Skubitz (2003), Arslan } \\
\text { et al. (2005), Zaitseva et al. (2006, 2007) and Yin } \\
\text { et al. (2013) }\end{array}$ \\
\hline
\end{tabular}


Research Ethics Committee and Southern Health Human Research Ethics Committee. Detailed clinical histories including menstrual cycle stage and menopause status were collected at the time of informed consent (Table 2). Women who received hormone treatment in the 3 months prior to surgery were excluded from the study.

Normal myometrium sample of at least $2 \mathrm{~cm}$ was taken from adjacent fibroid tissue. If more than one fibroid was present per uteri, a single sample of the largest visible fibroid was taken from the body. Patients were not stratified according to fibroid location (subserosal, submucosal or intramural); however, degenerative type fibroids (hyaline, calcification, cystic or red (haemorrhagic)) were excluded from the study. Tissues were collected in HEPES-buffered DMEM culture medium with $10 \%(\mathrm{v} / \mathrm{v})$ fetal bovine serum (FBS) and antibiotic-antimycotic solution (all from Life Technologies).

\section{Fluorescence-activated cell sorting}

Single-cell suspensions of myometrium and fibroid $(n=13$ pairs) cells were established as described previously (Gargett et al. 2002, Zaitseva et al. 2006). Myometrium and fibroid cell were separated into independent cell populations using five colour fluorescence-activated cell sorting (FACS) as previously described (Holdsworth-Carson et al. 2014). Briefly, leucocytes, endothelial cells and dead cells were removed following identification with CD45, CD31 and 4',6-diamidino-2-phenylindole (DAPI, for cell viability) respectively. Remaining cells were sorted based on CD90 positivity and aldehyde dehydrogenase 1 (ALDH1) using an ALDEFLUOR assay kit (StemCells Technologies, Tullamarine, VIC, Australia) and a MoFlo flow cytometer using Cyclops SUMMIT Software (version 4.1; Cytomation, Inc., Fort Collins, CO, USA). Cells were re-suspended in $\mathrm{PBS} / 5 \% \mathrm{FBS}(\mathrm{w} / \mathrm{v})$ and incubated with allophycocyanin-conjugated CD90 (1:100 or $2 \mu \mathrm{g} / \mathrm{ml}$, BD Biosciences, Franklin Lakes, NJ, USA), phycoerythrin cyanine 7 (PeCy7)-conjugated CD31 (1:100 or $2 \mu \mathrm{g} / \mathrm{ml}$, BioLegend, San Diego, CA, USA) and PeCy5.5-conjugated CD45 (1:100, Life Technologies) for $45 \mathrm{~min}$ at $4{ }^{\circ} \mathrm{C}$. Negative controls were stained with directly conjugated mouse $\lg \mathrm{G}$ antibodies at equivalent concentrations. Cells were washed, re-suspended in ALDEFLUOR assay buffer and incubated with ALDH substrate BODIPY-aminoacetaldehyde for $45 \mathrm{~min}$ at $37^{\circ} \mathrm{C}$. Negative controls were pre-treated with diethylaminobenzaldehyde, a

Table 2 Patient information.

\begin{tabular}{lcll}
\hline Patient & Age & Cycle stage & Menopause \\
\hline 1 & 50 & Proliferative & Pre- \\
2 & 52 & Proliferative & Pre- \\
3 & 46 & Proliferative & Pre- \\
4 & 46 & Proliferative & Pre- \\
5 & 51 & Proliferative & Pre- \\
6 & 49 & Proliferative & Pre- \\
7 & 44 & Proliferative & Pre- \\
8 & 45 & Secretory & Pre- \\
9 & 47 & Secretory & Pre- \\
10 & 46 & Shedding & Pre- \\
11 & 38 & Inactive & Pre- \\
12 & 43 & Inactive & Post- \\
13 & 52 & Inactive & Post- \\
\hline
\end{tabular}

specific inhibitor of ALDH. Cells were pelleted and re-suspended in ALDEFLUOR assay buffer containing DAPI $(1 \mu \mathrm{g} / \mathrm{ml}$, Sigma-Aldrich) for FACS analysis. Cells were separated into three myometrium and four fibroid sub-populations based on their $\mathrm{CD} 90$ and $\mathrm{ALDH}$ positivity: $\mathrm{ALDH}^{-} / \mathrm{CD}^{-}$ $\left(\mathrm{A}^{-} \mathrm{C}^{-}\right)$enriched for $\mathrm{VSMC}, \mathrm{ALDH}^{-} / \mathrm{CD}^{+}\left(\mathrm{A}^{-} \mathrm{C}^{+}\right)$enriched for $\mathrm{SMC}, \mathrm{ALDH}^{+} / \mathrm{CD}^{+} 0^{+}\left(\mathrm{A}^{+} \mathrm{C}^{+}\right)$enriched for fibroblasts and fibroid-specific $\mathrm{ALDH}^{-} / \mathrm{CD}^{+ \text {bright }}\left(\mathrm{A}^{-} \mathrm{C}^{+ \text {br }}\right)$ fibroblast cells (Holdsworth-Carson et al. 2014).

\section{RNA extraction, CDNA synthesis and qRT-PCR}

RNA was extracted from sorted cell sub-populations using the AllPrep DNA/RNA Micro Kit (with on-column DNase treatment; Qiagen) following the manufacturer's instructions. The number of cells ranged from $2.2 \times 10^{5}$ to $1.2 \times 10^{6}$ cells/subpopulation. RNA quality and concentration was assessed using a Nanodrop u.v. spectrophotometer (Thermo Fisher Scientific, Scoresby, VIC, Australia). RNA (5-50 ng/sample) was converted to cDNA using VILO cDNA synthesis kit (Life Technologies), diluted in DEPC-treated water $(1: 20)$ and stored at $-80^{\circ} \mathrm{C}$.

All qRT-PCR experiments were performed using a ViiA7 realtime PCR instrument (384-well format; Life Technologies), Universal Probe (Roche) or TaqMan (Life Technologies) assays. The list of the primers used in this study and their average $C_{\mathrm{t}}$ values are summarised in Table 3. Four microlitres of diluted CDNA (final dilution 1:50) was used per $10 \mu \mathrm{l}$ qRT-PCR using FastStart Universal Probe Master (Roche), in duplicate. Primers were used at $500 \mathrm{nM}$ and probes at $200 \mathrm{nM}$ /reaction. Amplification was performed for 40 cycles with annealing temperatures of $60{ }^{\circ} \mathrm{C}$ for all primers. Relative quantification was performed using the comparative $C_{\mathrm{t}}$ method $\left(2^{-\Delta \Delta C_{\mathrm{t}}}\right)$, with average $C_{\mathrm{t}}$ values of human $\beta$-2-microglobulin (B2M; VIC/MGB Probe, Life Technologies, catalogue number $4326319 \mathrm{E})$ and ribosomal protein L13a (RPL13A2) used as an endogenous control to correct for differences in concentration of the starting template (see Table 4 for the relevant $n$ numbers for each gene and each cell population). B2M and RPL13A2 were chosen as housekeeping genes for this study as they were stably expressed between myometrium and fibroid cell sub-populations and demonstrated minimal variability (data not shown). The ratio of $P R / P R B$ was calculated to represent the relative expression level of $P R A$ (VladicStjernholm et al. 2009).

Note that the expression of $E R \beta$ mRNA was low (Table 3); we were unable to amplify $E R \beta$ in $>25 \%$ of samples. It has been reported previously that endothelial cells, not SMC, express $E R \beta$ in myometrium and fibroids (Gargett et al. 2002). Owing to our FACS protocol, ER $\beta$-expressing endothelial cells were removed. Others have also had difficulties in detecting ER $\beta$ in fibroids (Yin et al. 2013).

\section{Immunocytochemistry and image analysis}

Selected sorted cell sub-populations were air-dried on frosted slides (sorted cells from $n=6$ paired myometrium and fibroid tissues). Cells were fixed with chilled acetone for $2 \mathrm{~min}$ and stored at $-20{ }^{\circ} \mathrm{C}$ until ready for use. Cells were washed with PBS prior to blocking endogenous peroxidases with $0.3 \%(\mathrm{v} / \mathrm{v})$ 
Table 3 Primer sequences and mean $C_{\mathrm{t}}$ values.

\begin{tabular}{|c|c|c|c|}
\hline Gene & Primer sequence & Universal probe library & Mean $C_{\mathrm{t}}$ \\
\hline ESR1 $(E R \alpha)$ & $\begin{array}{l}\text { F: ATCCACCTGATGGCCAAG } \\
\text { R: GCTCCATGCCTTTGTTACTCA }\end{array}$ & $\# 017$ & 29.01 \\
\hline$E S R 2(E R \beta)$ & $\begin{array}{l}\text { F: ATGATGGGGCTGATGTGG } \\
\text { R: TTCTACGCATTTCCCCTCA }\end{array}$ & $\# 050$ & 34.50 \\
\hline$P G R(P R)$ & $\begin{array}{l}\text { F: TTTAAGAGGGCAATGGAAGG } \\
\text { R: CGGATTTTATCAACGATGCAG }\end{array}$ & $\# 011$ & 29.72 \\
\hline$P G R(P R B)$ & $\begin{array}{l}\text { F: GACTGAGCTGAAGGCAAAGG } \\
\text { R: AAACTTCAGGCAAGGTGTCC }\end{array}$ & $\# 036$ & 31.97 \\
\hline TGFB1 & $\begin{array}{l}\text { F: ACTACTACGCCAAGGAGGTCAC } \\
\text { R: TGCTTGAACTTGTCATAGATTTCG }\end{array}$ & $\# 031$ & 28.91 \\
\hline TGFB3 & $\begin{array}{l}\text { F: GGGCTTTGGACACCAATTAC } \\
\text { R: GGCATAGTAGCCCTTAGGTTCA }\end{array}$ & $\# 011$ & 29.09 \\
\hline TGFBR1 & $\begin{array}{l}\text { F: AAATTGCTCGACGATGTTCC } \\
\text { R: CATAATAAGGCAGTTGGTAATCTTCA }\end{array}$ & $\# 031$ & 29.19 \\
\hline TGFBR2 & $\begin{array}{l}\text { F: TGTGGATGACCTGGCTAACA } \\
\text { R: CTCCAAATTCATCCTGGATTCT }\end{array}$ & $\# 050$ & 29.41 \\
\hline$C R A B P 2$ & $\begin{array}{l}\text { F: GGGTCTCTCTAAAGGGGACTTG } \\
\text { R: GGCTACAGGGACAAAGGGTAG }\end{array}$ & $\# 015$ & 29.21 \\
\hline RPL13A & $\begin{array}{l}\text { F: TGACCAATAGGAAGAGCAACC } \\
\text { R: AGATGCCCCACTCACAAGAT }\end{array}$ & $\# 036$ & 27.48 \\
\hline
\end{tabular}

$\mathrm{H}_{2} \mathrm{O}_{2}$ in methanol (10 min at room temperature (RT)) and then serum-free protein block (Dako, Glostop, Denmark) (10 min, RT). The cells were incubated with anti-goat CRABP2 antibody (Santa Cruz Biotechnology, Inc.) diluted 1:500 $(0.4 \mu \mathrm{g} / \mathrm{ml})$ in $1 \%(\mathrm{w} / \mathrm{v}) \mathrm{BSA} / \mathrm{PBS}$ overnight at $4{ }^{\circ} \mathrm{C}$. Incubation with goat IgG (Santa Cruz Biotechnology, Inc.; diluted to $0.4 \mu \mathrm{g} / \mathrm{ml}$ ) was also performed as a negative control. The following day, cells were incubated with biotinylated anti-goat secondary antibody 1:2000 (Life Technologies; 30 min, RT). CRABP2 was visualised following incubation with $A B C$ Vectastain Kit (Vector Laboratories, Burlingame, CA, USA; 5 min, RT) followed by 3,30'-diaminobenzidine (DAB; Sigma-Aldrich; $5 \mathrm{~min}, \mathrm{RT}$ ). Cells were then briefly counterstained in Harris haematoxylin (Amber Scientific, Midvale, WA, Australia).

Images were observed using a Zeiss Axioskop light microscope, AxioCam ICc 3 Zeiss camera and AxioVision System Software (release 4.6; Carl Zeiss Imaging Solutions, Munchen, Germany). Image analysis was performed using the ImmunoRatio automated image analysis program (Tuominen et al. 2010) as a plugin in Fiji (Image); http://fiji.sc/How_to_ cite_Fiji\%3F) (Schindelin et al. 2012). Three fields of view per sorted cell sub-population were analysed. Data are described as percentage of DAB staining/total cell area.

\section{Statistical analysis}

Statistical analysis was performed using SPSS (version 20, SPSS, Inc.). Analysis of qRT-PCR data was performed using non-parametric Kruskal-Wallis and Mann-Whitney $U$ tests $(P<0.05)$. To reduce the chance of obtaining false-positive results as a consequence of multiple pair-wise tests, a Bonferroni's correction was also applied so that any comparison was only considered significant if $P<0.0125$. CRABP2 protein expression analysis data were normally distributed and analysed by $t$-tests $(P<0.05)$.

\section{Results}

Three sub-populations of phenotypically different cells were compared between myometrial and fibroid isolates: $\mathrm{A}^{-} \mathrm{C}^{-} \operatorname{VSMC}$ (Fig. 1), $\mathrm{A}^{-} \mathrm{C}^{+} \mathrm{SMC}$ (Fig. 2) and $\mathrm{A}^{+} \mathrm{C}^{+}$fibroblasts (Fig. 3). Although multiple phenotypically different cell types exist in fibroids, these cells are clonal in origin (Holdsworth-Carson et al. 2014). Therefore, a comparison of the genes of interest between the four clonal sub-populations from fibroids $\left(\mathrm{A}^{-} \mathrm{C}^{-}\right.$, $\mathrm{A}^{-} \mathrm{C}^{+}, \mathrm{A}^{+} \mathrm{C}^{+}$and $\mathrm{A}^{-} \mathrm{C}^{+\mathrm{br}}$ ) was also performed (Fig. 4).

Table 4 Number of patients included in qRT-PCR analysis.

\begin{tabular}{|c|c|c|c|c|c|c|c|}
\hline & \multicolumn{7}{|c|}{ Number of patients included in qRT-PCR analysis } \\
\hline & \multicolumn{3}{|c|}{ Myometrium derived } & \multicolumn{4}{|c|}{ Fibroid derived } \\
\hline & $\mathrm{A}^{-} \mathrm{C}^{-}$ & $\mathrm{A}^{-} \mathrm{C}^{+}$ & $\mathrm{A}^{+} \mathrm{C}^{+}$ & $\mathrm{A}^{-} \mathrm{C}^{-}$ & $\mathrm{A}^{-} \mathrm{C}^{+}$ & $\mathrm{A}^{+} \mathrm{C}^{+}$ & $\mathrm{A}^{-} \mathrm{C}^{+} \mathrm{br}$ \\
\hline ESR1 $(E R \alpha)$ & 13 & 13 & 13 & 13 & 13 & 12 & 12 \\
\hline ESR2 (ERß) & 9 & 9 & 12 & 10 & 11 & 8 & 8 \\
\hline$P G R(P R)$ & 12 & 13 & 13 & 13 & 13 & 12 & 12 \\
\hline$P G R(P R B)$ & 13 & 13 & 13 & 13 & 13 & 12 & 12 \\
\hline TGFB1 & 13 & 13 & 13 & 13 & 13 & 12 & 12 \\
\hline TGFB3 & 13 & 13 & 13 & 13 & 13 & 12 & 12 \\
\hline TGFBR 1 & 13 & 13 & 13 & 13 & 13 & 12 & 13 \\
\hline TGFBR2 & 13 & 13 & 13 & 13 & 13 & 12 & 12 \\
\hline$C R A B P 2$ & 13 & 13 & 13 & 13 & 13 & 12 & 12 \\
\hline RPL 13A & 12 & 13 & 13 & 13 & 13 & 12 & 12 \\
\hline
\end{tabular}



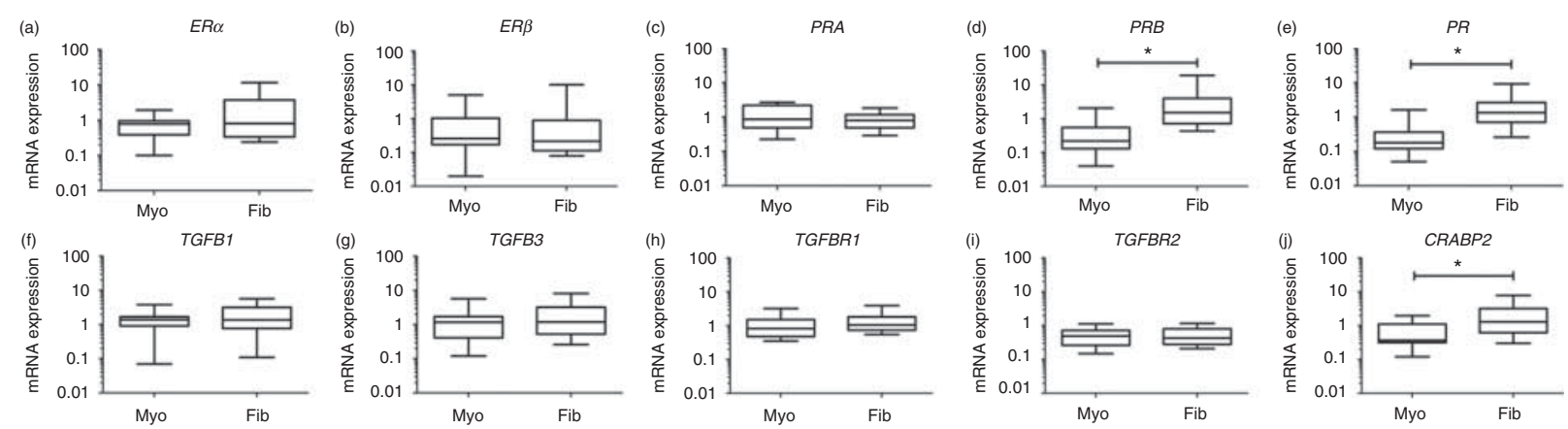

Figure 1 Gene expression in the $\mathrm{A}^{-} \mathrm{C}^{-}$vascular smooth muscle cell sub-population derived from paired myometrium (Myo) and fibroid (Fib). Relative mRNA expression is displayed for (a) ER $\alpha$, (b) $E R \beta$, (c) PRA (ratio of PR:PRB), (d) PRB, (e) PR, (f) TGFB1, (g) TGFB3, (h) TGFBR1, (i) TGFBR2 and (j) $C R A B P 2$. Data were analysed by non-parametric Kruskal-Wallis and Mann-Whitney $U$ tests, with significant difference denoted by $*(P<0.0125)$.

The same genes demonstrated differential mRNA expression between myometrium-derived cell populations and fibroid-derived cell populations. PRB and CRABP2 mRNA were increased in fibroid-derived $\mathrm{A}^{-} \mathrm{C}^{-} \mathrm{VSMC}$ compared with myometrium-derived cells $(P R B, P=0.001$ and $C R A B P 2, P=0.004$; Fig. $1 \mathrm{~d}$ and j). Similarly, $P R B$ and CRABP2 mRNA expression in $\mathrm{A}^{-} \mathrm{C}^{+} \mathrm{SMC}$ from fibroid origin was increased relative to those derived from myometrium ( $P R B, P=0.001$ and $C R A B P 2, P=0.026$; Fig. $2 \mathrm{~d}$ and j). $P R$ mRNA (which represents total $P R A$ and PRB mRNA, Vladic-Stjernholm et al. (2009)) was similarly increased in fibroid-derived $\mathrm{A}^{-} \mathrm{C}^{-}$VSMC $(P=0.001)$ (Fig. 1e) and $\mathrm{A}^{-} \mathrm{C}^{+} \mathrm{SMC}(P=0.003 ;$ Fig. 2e) relative to myometrial cell populations. When comparing the clonal fibroid cell sub-populations with each other, CRABP2 mRNA was significantly increased in the $\mathrm{A}^{+} \mathrm{C}^{+}$fibroblast population compared with both $\mathrm{A}^{-} \mathrm{C}^{+ \text {br }}$ fibroblasts $(P=0.003)$ and $\mathrm{A}^{-} \mathrm{C}^{-} \operatorname{VSMC}(P=0.024)$ (Fig. 4j).

Of the TGFB pathway genes investigated, only TGFBR2 mRNA expression in myometrium-derived $\mathrm{A}^{-} \mathrm{C}^{+} \mathrm{SMC}$ increased significantly when compared with fibroid $\mathrm{A}^{-} \mathrm{C}^{+} \mathrm{SMC}(P=0.029$; Fig. 2i). Expression of TGFB1, TGFB3, TGFBR1,ER $\alpha, E R \beta$ and PRA mRNA was not different between any of the cell sub-populations isolated from myometrium or fibroid (Figs 1, 2, 3 and 4).
None of the genes examined demonstrated significant changes in expression between myometrium and fibroid in $\mathrm{A}^{+} \mathrm{C}^{+}$fibroblasts (Fig. 3).

As demonstrated in Table 2, the patients included in this study were of mixed endometrial stage (different menstrual cycle stages and menopausal status). When qRT-PCR data were stratified into more uniform groups, for example, inclusion of only proliferative phase women $(n=7)$ or only pre-menopausal women $(n=11)$, the differential expression of $C R A B P 2, P R B$ $(P R)$ and TGFBR2 mRNA remained statistically significant (data not shown).

$C R A B P 2$ mRNA gene expression was most commonly altered between isolated cell sub-populations; therefore, CRABP2 immunocytochemistry was performed to determine whether altered expression extended to CRABP2 protein expression. Fibroid-associated $\mathrm{A}^{-} \mathrm{C}^{-}$ VSMC (Fig. 5b) and $\mathrm{A}^{-} \mathrm{C}^{+}$SMC (Fig. 5e) subpopulations displayed stronger CRABP2 immunostaining compared with their respective myometrium-derived cell populations (Fig. 5a and d). This was confirmed by quantitative image analysis, where the percentage of CRABP2-positive $\mathrm{A}^{-} \mathrm{C}^{-}$cells was significantly increased in fibroid populations compared with myometrial $\mathrm{A}^{-} \mathrm{C}^{-}$cells $(P=0.001$; Fig. $5 \mathrm{c})$. Similarly, the
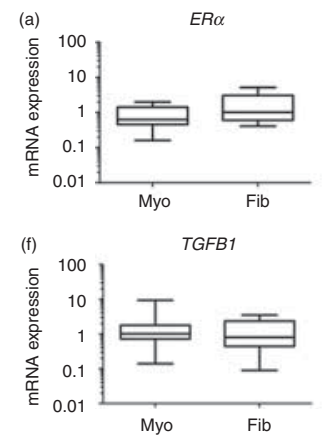
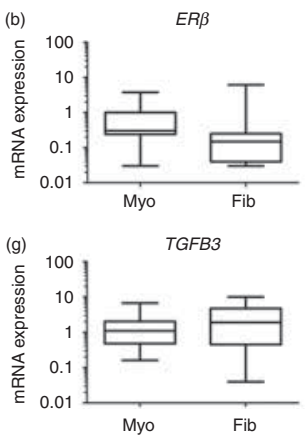
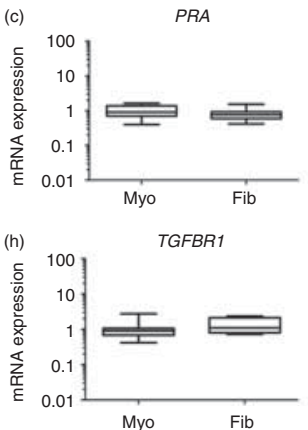
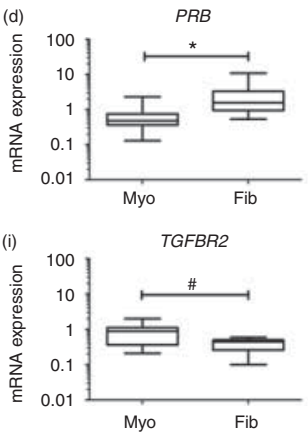

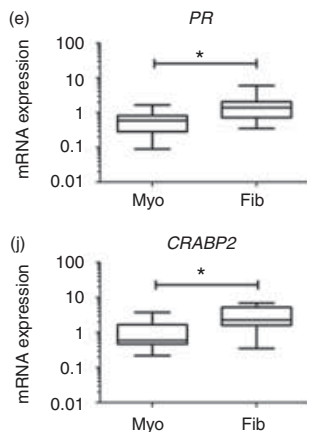

Figure 2 Gene expression in the $\mathrm{A}^{-} \mathrm{C}^{+}$smooth muscle cell sub-population derived from paired myometrium (Myo) and fibroid (Fib). Relative mRNA expression is displayed for (a) $E R \alpha$, (b) $E R \beta$, (c) PRA (ratio of PR:PRB), (d) PRB, (e) PR, (f) TGFB1, (g) TGFB3, (h) TGFBR1, (i) TGFBR2 and (j) CRABP2. Data were analysed by non-parametric Kruskal-Wallis and Mann-Whitney $U$ tests, with significant difference denoted by $*(P<0.0125)$ and ${ }^{\#}(P<0.05)$. 

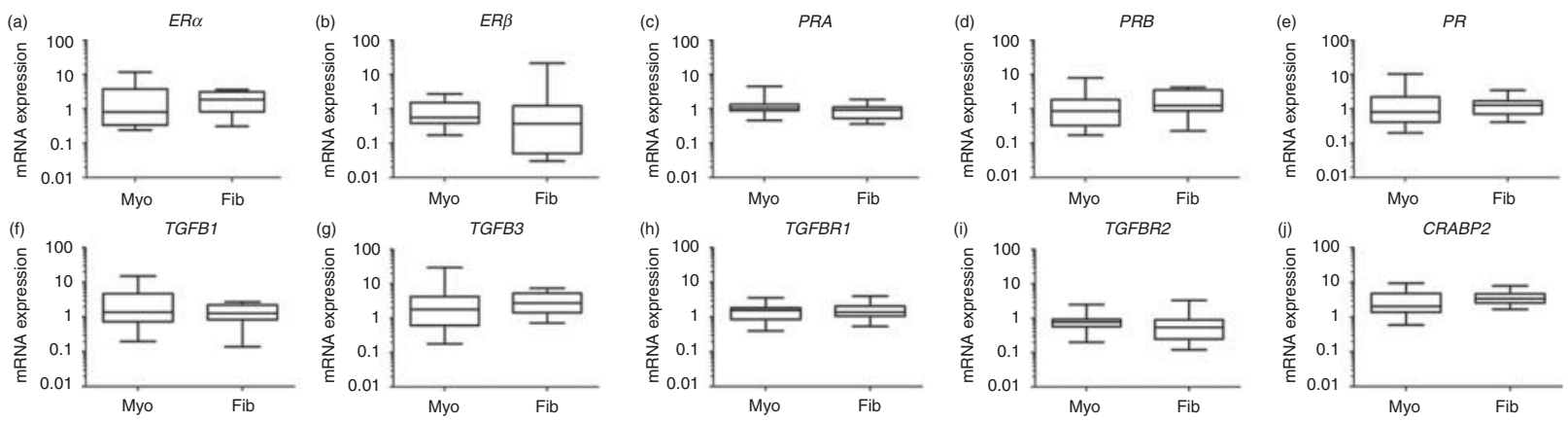

Figure 3 Gene expression in the $\mathrm{A}^{+} \mathrm{C}^{+}$fibroblast cell sub-population derived from paired myometrium (Myo) and fibroid (Fib). Relative mRNA expression is displayed for (a) $E R \alpha$, (b) $E R \beta$, (c) PRA (ratio of PR:PRB), (d) PRB, (e) PR, (f) TGFB1, (g) TGFB3, (h) TGFBR1, (i) TGFBR2 and (j) CRABP2. Data were analysed by non-parametric Kruskal-Wallis and Mann-Whitney $U$ tests.

percentage of CRABP2-positive $\mathrm{A}^{-} \mathrm{C}^{+} \mathrm{SMC}$ was significantly increased in fibroid populations relative to myometrium $\mathrm{A}^{-} \mathrm{C}^{+} \mathrm{SMC}(P=0.010 ;$ Fig. 5f). In contrast, fibroid-derived fibroblast cell populations demonstrated greater variability in CRABP2 protein expression (Fig. $5 \mathrm{~g}$ and $h$ ) and consequently did not differ significantly between $\mathrm{A}^{+} \mathrm{C}^{+}$and $\mathrm{A}^{-} \mathrm{C}^{+ \text {br }}$ cell sub-populations $(P=0.227$; Fig. 5i).

\section{Discussion}

Fibroblasts are an integral cellular component of human uterine fibroids and myometrium (Koumas et al. 2001,
Zaitseva et al. 2007, Moore et al. 2010, HoldsworthCarson et al. 2014). Although fibroids are clonal, significant cellular heterogeneity exists (HoldsworthCarson et al. 2014). This is the first study to recognise the heterogeneous nature of uterine fibroid and myometrial cell phenotypes and sort tissues into specific cell sub-populations $\left(\mathrm{A}^{-} \mathrm{C}^{-}\right.$VSMC, $\mathrm{A}^{-} \mathrm{C}^{+} \mathrm{SMC}, \mathrm{A}^{+} \mathrm{C}^{+}$ fibroblasts and $\mathrm{A}^{-} \mathrm{C}^{+\mathrm{br}}$ fibroid fibroblast) prior to examining genes known to be differentially expressed in fibroids and fibroblast-associated tumorigenesis. We hypothesised that cell populations isolated from fibroid and myometrium would differ in the expression of fibroid- and fibroblast-associated genes. $C R A B P 2, P R B$
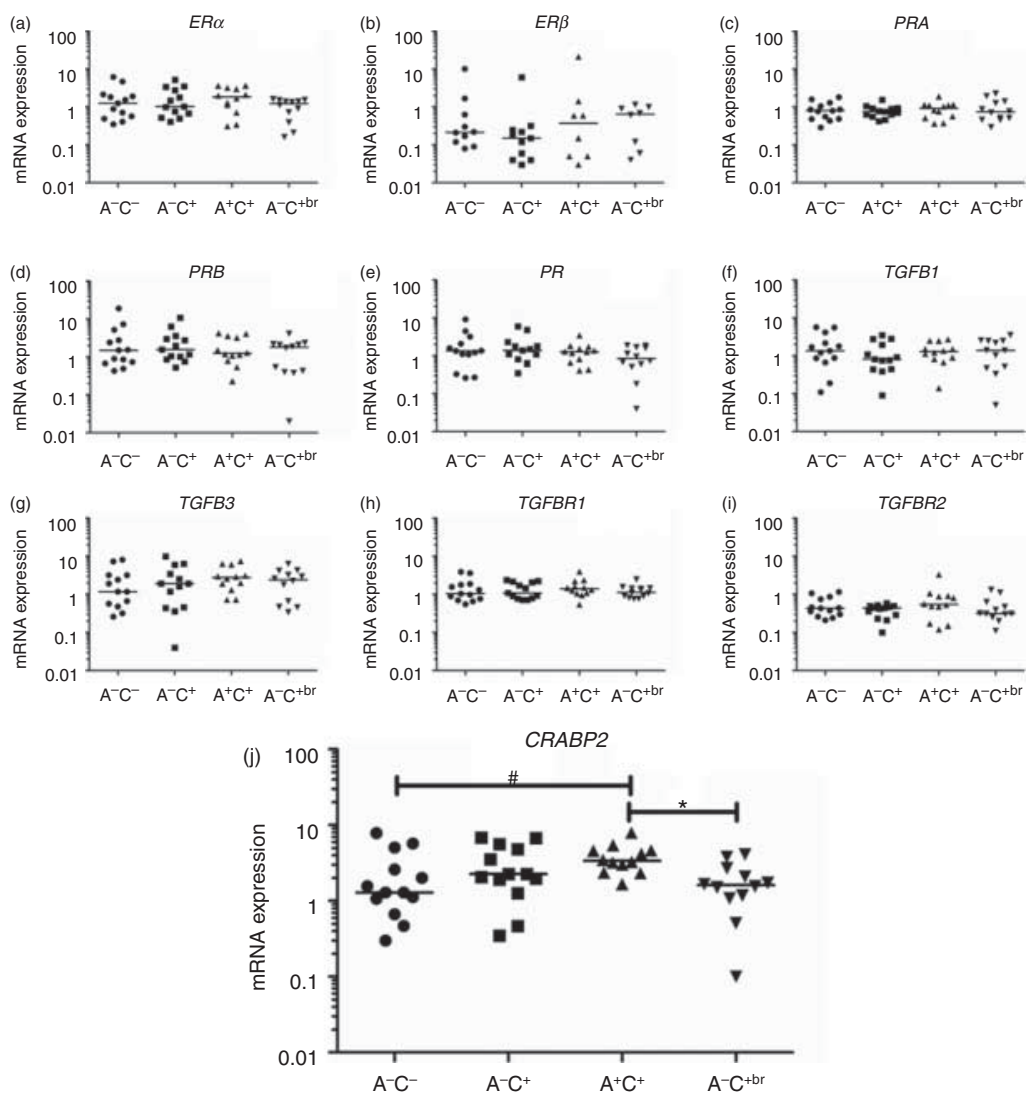

Figure $4 \mathrm{~A}$ comparison of the gene expression in fibroidderived $\mathrm{A}^{-} \mathrm{C}^{-}, \mathrm{A}^{-} \mathrm{C}^{+}, \mathrm{A}^{+} \mathrm{C}^{+}$and $\mathrm{A}^{-} \mathrm{C}^{+ \text {br }}$ cell subpopulations. Relative mRNA expression is displayed for (a) $E R \alpha$, (b) $E R \beta$, (c) $P R A$ (ratio of $P R: P R B$ ), (d) $P R B$, (e) $P R$, (f) TGFB1, (g) TGFB3, (h) TGFBR1, (i) TGFBR2 and (j) $C R A B P 2$. Data are displayed as scatter plots with medians. Data were analysed by non-parametric Kruskal-Wallis and Mann-Whitney $U$ tests, with significant difference denoted by $*(P<0.0125)$ or $\#(P<0.05)$. 

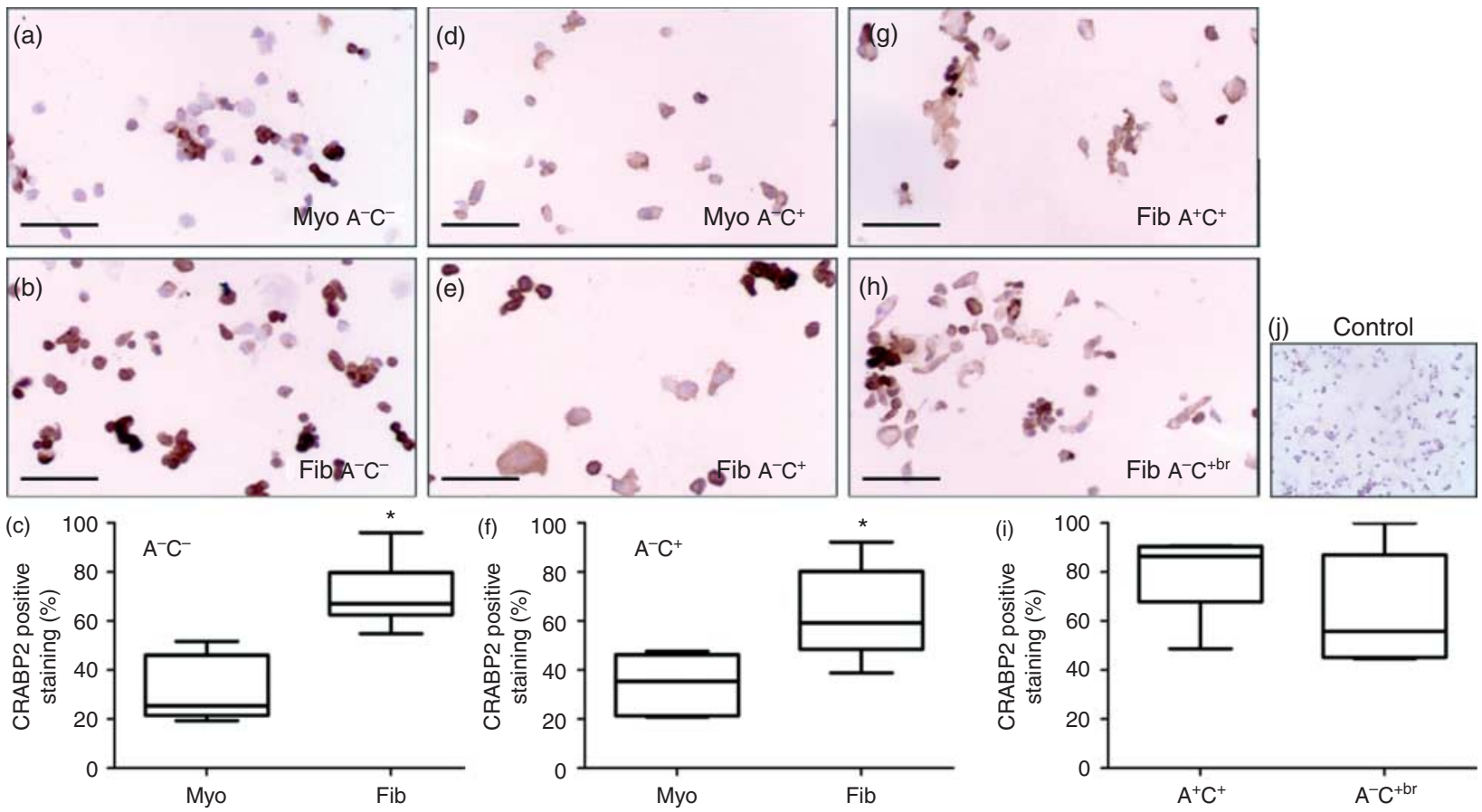

Figure 5 CRABP2 immunocytochemistry on $\mathrm{A}^{-} \mathrm{C}^{-}, \mathrm{A}^{-} \mathrm{C}^{+}, \mathrm{A}^{+} \mathrm{C}^{+}$and $\mathrm{A}^{-} \mathrm{C}^{+\mathrm{br}}$ sub-populations derived from paired myometrium (Myo) and fibroid (Fib) ( $n=6$ patients). Images show representative CRABP2 (brown) staining for (a) Myo $\mathrm{A}^{-} \mathrm{C}^{-}$and (b) Fib $\mathrm{A}^{-} \mathrm{C}^{-}$, (d) $\mathrm{Myo} \mathrm{A}^{-} \mathrm{C}^{+}$and (e) Fib A ${ }^{-} \mathrm{C}^{+}$, and (g) Fib $A^{+} C^{+}$and (h) Fib $A^{-} C^{+b r}$. Scale bar $=50 \mu \mathrm{m}$. Isotype negative control (j). CRABP2 image analysis quantification was performed on (c) Myo (pink) vs Fib (purple) $\mathrm{A}^{-} \mathrm{C}^{-}$vascular smooth muscle cells, (f) Myo (pink) vs Fib (purple) $\mathrm{A}^{-} \mathrm{C}^{+}$smooth muscle cells and (i) Fib $\mathrm{A}^{+} \mathrm{C}^{+}$(purple) vs $\mathrm{Fib} \mathrm{A}^{-} \mathrm{C}^{+\mathrm{br}}$ (pale purple) fibroblasts cells. Data were analysed by $t$-test, with significant difference denoted by $*(P<0.0125)$.

(and $P R$ ) and TGFBR2 gene expression was found to be different between fibroid- and myometrium-derived cell populations. CRABP2 gene expression was also altered between clonal fibroid sub-populations, and these differences were confirmed at the protein level.

Fibroid development, symptomology, demographics and response to treatment is heterogeneous (Peddada et al. 2008, Davis et al. 2009, Zhao \& Rogers 2013). This is reflected in our sample group (Table 1). We hypothesised that expression of genes known to be altered in association with fibroids would also be altered in different sub-populations of cells isolated from fibroid and myometrial tissues. This hypothesis was upheld, even in our relatively small and mixed patient population. Even when data were stratified using smaller, more homogeneous patient sets (for example, proliferative phase only, or pre-menopausal only), the differential gene expression remained statistically significant. This finding demonstrates that despite the heterogeneous phenotype of uterine fibroids, common gene pathways are dysregulated between phenotypically dissimilar cellular components of fibroids.

The RA pathway has pleiotropic effects in various processes, including cell growth, differentiation and apoptosis. CRABP2 binds with and delivers all-trans-RA (ATRA) to the nucleus where it then binds and activates retinoid receptors (RAR and RXR) (reviewed by Rhinn \& Dollé (2012)). CRABP2 expression has been shown to be increased in whole fibroid tissues relative to myometrial tissue (Tsibris et al. 2002, Arslan et al. 2005, Zaitseva et al. 2006, 2007). In this study, we demonstrate that fibroid-derived $\mathrm{A}^{-} \mathrm{C}^{-} \mathrm{VSMC}$ and $\mathrm{A}^{-} \mathrm{C}^{+}$SMC similarly express increased levels of $C R A B P 2 \mathrm{mRNA}$ and protein relative to their myometrium-derived equivalents. Elevated CRABP1 and CRABP2 mRNA expression is associated with myoblast differentiation in vivo and in vitro, implicating an important role for CRABPs in myogenesis (Tang et al. 2007, Jing et al. 2013). As for fibroid research, the concept of cellular heterogeneity and differential SMC-subset modulation is also recognised in the field of atherosclerosis (Seidel 1997, Neuville et al. 1999). In rats, two phenotypically distinct arterial SMC populations behave differently in response to ATRA and/or RAR/RXR agonists (Neuville et al. 1999). Expression of CRABP2 is associated with cells that metabolise large quantities of RA, indicating that cells with high $R A$ requirements increase both $R A$ synthesis and the level of CRABP2 expression, thus providing efficient delivery of RA to its cognate receptors (Noy 2000). Interestingly, extracts from human tissue show more than fourfold higher ATRA levels in uterine fibroids compared with myometrium (Tsibris et al. 1999); however, others have observed reduced ATRA concentrations in fibroids (Catherino \& Malik 2007). ATRA has also been shown to regulate downstream transcriptional pathways in myometrial mixed cultures (Zaitseva et al. 2013). 
RA-mediated apoptosis signalling has been identified as a canonical pathway involved with differential fibroid growth (Davis et al. 2013). RA signalling can also promote cell survival and proliferation via anti-apoptotic mechanisms; however, these pro-survival properties of RA are unlikely to be mediated by its cognate RAR and instead an alternative receptor, peroxisome proliferator-activated receptor $\beta / \delta$, may be employed (Noy 2010). It is therefore hypothesised that fibroid VSMC and SMC act independently of myometrial sub-populations, dysregulating the RA signalling pathway via abnormal $C R A B P 2$ expression, thus contributing to fibroid progression.

We also identified that $C R A B P 2$ gene expression was altered in clonal sub-populations derived from within the fibroid itself, being elevated in $\mathrm{A}^{+} \mathrm{C}^{+}$fibroblasts relative to $\mathrm{A}^{-} \mathrm{C}^{+ \text {br }}$ fibroblasts and $\mathrm{A}^{-} \mathrm{C}^{-}$VSMC. We have previously hypothesised that the four subpopulations identified in uterine fibroids are clonally amplified from a progenitor cell that differentiates into SMC, VSMC and fibroblast cells (Holdsworth-Carson et al. 2014). Clonal pluripotent cells, including human embryonal carcinoma NT2 cells, have the capacity to differentiate into several cell types. NT2 cells induced to differentiate with RA demonstrate increased $C R A B P 2$ expression and it is suggested that $C R A B P 2$ upregulation correlates with increased RA sensitivity during differentiation (Borghi et al. 2003). Studies on melanoma have identified that these tumours induce restricted production of RA within the tumour microenvironment (with much higher RA concentration compared with surrounding tissues; Guo et al. 2012). Interestingly, only selective cells within this microenvironment were responsible for ATRA accumulation (Guo et al. 2012). We suggest that within the fibroid microenvironment, $\mathrm{A}^{+} \mathrm{C}^{+}$fibroblasts are responsible for primary aberrant $\mathrm{RA}$ signalling via up-regulated $C R A B P 2$ expression, and subsequent paracrine actions of $\mathrm{A}^{+} \mathrm{C}^{+}$fibroblasts go on to mediate cell survival, proliferation and fibroid growth.

There is significant evidence in the literature supporting a progesterone- and TGFB-mediated role in the proliferation of uterine fibroids (reviewed by Rein et al. (1995), Ciarmela et al. (2011) and Kim \& Sefton (2012)). TGFBR2 gene expression was decreased in fibroidderived $\mathrm{A}^{-} \mathrm{C}^{+} \mathrm{SMC}$ relative to myometrium. This is in contrast to whole tissue data, where TFGBR2 expression is increased in fibroid tissues compared with myometrial tissues (Dou et al. 1996). However, studies of total or partial knockout of Tgfbr2 in mice have associated TGFBR2 loss with enhanced mammary tumour progression (Fang et al. 2011). Up to $70 \%$ of uterine fibroids carry a mutation in the mediator complex subunit 12 (Med12) gene on chromosome Xq13.1 (Mäkinen et al. 2011). Since individual cell populations derived from fibroids are clonal (Holdsworth-Carson et al. 2014), all Med12 mutation-positive cell populations should carry the mutation. MED12 makes up part of the mediator complex and additionally interacts with several proteins including $\beta$-catenin (Wnt signalling) and GLI3 (Sonic hedgehog signalling), which others and we have identified in association with uterine fibroids (Tanwar et al. 2009, Mäkinen et al. 2011, Zaitseva et al. 2013). Recent studies have shown that MED12 interacts with and up-regulates TGFBR2 and TGFB signalling (Huang et al. 2012). Although we did not screen our samples for Med12 mutations, the reduction in TGFBR2 expression in our $\mathrm{A}^{-} \mathrm{C}^{+}$SMC fibroid subpopulation may reflect an inherent loss of MED12 functionality as a consequence of this common fibroid-associated gene mutation.

$P R B$ (and $P R$ ) gene expression was increased in $\mathrm{A}^{-} \mathrm{C}^{-}$ VSMC and $\mathrm{A}^{-} \mathrm{C}^{+}$SMC derived from fibroid tissues compared with myometrium. Previously, studies have reported an increase in $P R$ in association with whole fibroid tissues (Sadan et al. 1987, Lee et al. 2010). Elevated $P R$ expression in VSCM and SMC may have anti-apoptotic properties, whereby progesterone plays a role in triggering $\mathrm{BCL} 2$ protein expression in human uterine fibroid cultures (Matsuo et al. 1997). Similar to the myometrium, breast and endometrial tissues also display cellular heterogeneity, and in these tissues, PR expression has been demonstrated to be cell-type specific (Snijders et al. 1992, Shyamala et al. 1997, Mote et al. 2000). In both breast and endometrium, PR is regulated by, and functions via, paracrine mechanisms in sub-sets of cells (typically epithelial; Brisken et al. 1998, Kurita et al. 2000). Emphasising the mitotic proliferative effects of PR on uterine fibroid growth, therapeutic PR antagonists including ulipristal acetate have been demonstrated to reduce fibroid size, bleeding and pain/ discomfort in well-controlled pilot studies (Donnez et al. 2012). $A^{-} C^{+}$SMC and $A^{-} C^{-}$VSMC sub-populations respectively are the largest populations of cells isolated from uterine fibroids (Holdsworth-Carson et al. 2014). Inhibition of VSMC and SMC proliferation potential by antiprogestins is a plausible approach for controlling PR effects and thus ameliorating fibroid growth.

In conclusion, we have demonstrated that phenotypically different cellular constituents of uterine fibroids differentially express genes with known involvement in fibroid pathophysiology. In particular, CRABP2, a component of the RA differentiation pathway, and $P R B$ demonstrated altered gene expression in fibroid-derived cells of VSMC and SMC phenotype. Despite the inherent heterogeneity in our sample group, these genes demonstrated significant differences in expression in association with fibroid origin. CRABP2 is also a potential mediator of differentiation of fibroblasts and VSMC subpopulations within clonal fibroid tumours. It is possible that RA and PR-regulated transcription may control the expression of secretory factors in the tumour microenvironment by fibroid-associated SMC and fibroblasts and affect cell proliferation through paracrine mechanisms. We conclude that differential regulation of RA, TGFB and PR pathway transcription occurs in 
fibroid-associated SMC and fibroblasts and that investigation of paracrine interactions between different cell types within fibroids provides an important new paradigm for investigating the pathophysiology of this common disease.

\section{Declaration of interest}

The authors declare that there is no conflict of interest that could be perceived as prejudicing the impartiality of the research reported.

\section{Funding}

This work was supported by National Health and Medical Research Council (606613 to P A W Rogers and B J Vollenhoven).

\section{Acknowledgements}

The authors would like to acknowledge Dr Matt Burton from Scientific Services: Flow Cytometry \& Confocal Microscopy at the Murdoch Children's Research Institute Royal Children's Hospital (Parkville, VIC, Australia) and James Ngui from the Flow Cytometry Facility, Monash Medical Centre (Clayton, VIC, Australia). They also thank research nurses Nancy Taylor, Frances Walker, Lee Ann Mahoney and Lorraine Thompson for tissue collection and finally to all the women who kindly donated their tissue to this study.

\section{References}

Arslan AA, Gold LI, Mittal K, Suen T-C, Belitskaya-Levy I, Tang M-S \& Toniolo P 2005 Gene expression studies provide clues to the pathogenesis of uterine leiomyoma: new evidence and a systematic review. Human Reproduction 20 852-863. (doi:10.1093/humrep/deh698)

Borghi R, Vene R, Arena G, Schubert D, Albini A \& Tosetti F 2003 Transient modulation of cytoplasmic and nuclear retinoid receptors expression in differentiating human teratocarcinoma NT2 cells. Journal of Neurochemistry 84 94-104. (doi:10.1046/j.1471-4159.2003.01501.x)

Brisken C, Park S, Vass T, Lydon JP, O'Malley BW \& Weinberg RA 1998 A paracrine role for the epithelial progesterone receptor in mammary gland development. PNAS 95 5076-5081. (doi:10.1073/pnas.95.9.5076)

Cardozo ER, Clark AD, Banks NK, Henne MB, Stegmann BJ \& Segars JH 2012 The estimated annual cost of uterine leiomyomata in the United States. American Journal of Obstetrics and Gynecology 206 211.e1-211.e9. (doi:10.1016/j.ajog.2011.12.002)

Catherino WH \& Malik M 2007 Uterine leiomyomas express a molecular pattern that lowers retinoic acid exposure. Fertility and Sterility $\mathbf{8 7}$ 1388-1398. (doi:10.1016/j.fertnstert.2006.11.093)

Chottanapund S, Van Duursen MB, Navasumrit P, Hunsonti P, Timtavorn S, Ruchirawat M \& Van den Berg M 2013 Effect of androgens on different breast cancer cells co-cultured with or without breast adipose fibroblasts. Journal of Steroid Biochemistry and Molecular Biology 138 54-62. (doi:10.1016/j.jsbmb.2013.03.007)

Ciarmela P, Islam MS, Reis FM, Gray PC, Bloise E, Petraglia F, Vale W \& Castellucci M 2011 Growth factors and myometrium: biological effects in uterine fibroid and possible clinical implications. Human Reproduction Update 17 772-790. (doi:10.1093/humupd/dmr031)

Davis B, Haneke K, Miner K, Kowalik A, Barrett JC, Peddada S \& Baird D 2009 The fibroid growth study: determinants of therapeutic intervention. Journal of Women's Health 18 725-732. (doi:10.1089/jwh.2008.0903)
Davis BJ, Risinger JI, Chandramouli GVR, Bushel PR, Baird DD \& Peddada SD 2013 Gene expression in uterine leiomyoma from tumors likely to be growing (from black women over 35) and tumors likely to be non-growing (from white women over 35). PLOS ONE 8 e63909. (doi:10.1371/journal.pone.0063909)

Delacroix L, Moutier E, Altobelli G, Legras S, Poch O, Choukrallah M-A, Bertin I, Jost B \& Davidson I 2010 Cell-specific interaction of retinoic acid receptors with target genes in mouse embryonic fibroblasts and embryonic stem cells. Molecular and Cellular Biology 30 231-244. (doi:10.1128/MCB.00756-09)

Donnez J, Tatarchuk TF, Bouchard P, Puscasiu L, Zakharenko NF, Ivanova T, Ugocsai G, Mara M, Jilla MP, Bestel E et al. 2012 Ulipristal acetate versus placebo for fibroid treatment before surgery. New England Journal of Medicine 366 409-420. (doi:10.1056/NEJMoa1103182)

Dou Q, Zhao Y, Tarnuzzer RW, Rong H, Williams RS, Schultz GS \& Chegini N 1996 Suppression of transforming growth factor- $\beta$ (TGF $\beta$ ) and TGF $\beta$ receptor messenger ribonucleic acid and protein expression in leiomyomata in women receiving gonadotropin-releasing hormone agonist therapy. Journal of Clinical Endocrinology and Metabolism 81 3222-3230.

Elenbaas B \& Weinberg RA 2001 Heterotypic signaling between epithelial tumor cells and fibroblasts in carcinoma formation. Experimental Cell Research 264 169-184. (doi:10.1006/excr.2000.5133)

Fang W, Jokar I, Chytil A, Moses H, Abel T \& Cheng N 2011 Loss of one Tgfbr2 allele in fibroblasts promotes metastasis in MMTV: polyoma middle $\mathrm{T}$ transgenic and transplant mouse models of mammary tumor progression. Clinical \& Experimental Metastasis 28 351-366. (doi:10. 1007/s10585-011-9373-0)

Gargett CE, Bucak K, Zaitseva M, Chu S, Taylor N, Fuller PJ \& Rogers PAW 2002 Estrogen receptor- $\alpha$ and $-\beta$ expression in microvascular endothelial cells and smooth muscle cells of myometrium and leiomyoma. Molecular Human Reproduction 8 770-775. (doi:10.1093/molehr/8.8.770)

Guo Y, Pino-Lagos K, Ahonen CA, Bennett KA, Wang J, Napoli JL, Blomhoff R, Sockanathan S, Chandraratna RA, Dmitrovsky E et al. 2012 A retinoic acid - rich tumor microenvironment provides clonal survival cues for tumor-specific CD8 + T cells. Cancer Research 72 5230-5239. (doi:10.1158/0008-5472.CAN-12-1727)

Haslam S \& Woodward T 2003 Host microenvironment in breast cancer development: epithelial-cell-stromal-cell interactions and steroid hormone action in normal and cancerous mammary gland. Breast Cancer Research 5 208-215. (doi:10.1186/bcr615)

Holdsworth-Carson SJ, Zaitzeva M, Vollenhoven BJ \& Rogers PAW 2014 Clonality of smooth muscle and fibroblast cell populations isolated from human fibroid and myometrial tissues. Molecular Human Reproduction 20 250-259. (doi:10.1093/molehr/gat083)

Huang S, Hölzel M, Knijnenburg T, Schlicker A, Roepman P, McDermott U, Garnett M, Grernrum W, Sun C, Prahallad A et al. 2012 MED12 controls the response to multiple cancer drugs through regulation of TGF- $\beta$ receptor signaling. Cell 151 937-950. (doi:10.1016/j.cell.2012.10.035)

Jing Y, Zhonglin T, Shulin Y \& Kui L 2013 CRABP2 promotes myoblast differentiation and is modulated by the transcription factors MyoD and Sp1 in C2C12 cells. PLOS ONE 8 1-9. (doi:10.1371/journal.pone. 0055479)

Kim JJ \& Sefton EC 2012 The role of progesterone signaling in the pathogenesis of uterine leiomyoma. Molecular and Cellular Endocrinology 358 223-231. (doi:10.1016/j.mce.2011.05.044)

Koumas L, King AE, Critchley HO, Kelly RW \& Phipps RP 2001 Fibroblast heterogeneity: existence of functionally distinct Thy $1(+)$ and Thy $1(-)$ human female reproductive tract fibroblasts. American Journal of Pathology 159 925-935. (doi:10.1016/S0002-9440(10)61768-3)

Kurita T, Lee K-J, Cooke PS, Taylor JA, Lubahn DB \& Cunha GR 2000 Paracrine regulation of epithelial progesterone receptor by estradiol in the mouse female reproductive tract. Biology of Reproduction 62 821-830. (doi:10.1095/biolreprod62.4.831)

Lee EJ, Bajracharya P, Lee DM, Cho KH, Kim KJ, Bae YK, Kim MJ, Lee KH, Kim HJ, Song GH et al. 2010 Gene expression profiles of uterine normal myometrium and leiomyoma and their estrogen responsiveness in vitro. Korean Journal of Pathology 44 272-283. (doi:10.4132/KoreanJPathol. 2010.44.3.272)

Leppert PC, Catherino WH \& Segars JH 2006 A new hypothesis about the origin of uterine fibroids based on gene expression profiting with microarrays. American Journal of Obstetrics and Gynecology 195 415-420. (doi:10.1016/j.ajog.2005.12.059) 
Litovkin KV, Ivanova OV, Bauer A, Hoheisel JD, Bubnov VV \& Zaporozhan VN 2008 Microarray study of gene expression in uterine leiomyoma. Experimental Oncology 30 106-111.

Mäkinen N, Mehine M, Tolvanen J, Kaasinen E, Li Y, Lehtonen HJ, Gentile M, Yan J, Enge M, Taipale M et al. 2011 MED12, the mediator complex subunit 12 gene, is mutated at high frequency in uterine leiomyomas. Science 334 252-255. (doi:10.1126/science.1208930)

Malik M, Webb J \& Catherino WH 2008 Retinoic acid treatment of human leiomyoma cells transformed the cell phenotype to one strongly resembling myometrial cells. Clinical Endocrinology 69 462-470. (doi:10.1111/j.1365-2265.2008.03207.x)

Matsuo H, Maruo T \& Samoto T 1997 Increased expression of Bcl-2 protein in human uterine leiomyoma and its up-regulation by progesterone. Journal of Clinical Endocrinology and Metabolism 82 293-299.

Moore AB, Yu L, Swartz CD, Zheng XL, Wang L, Castro L, Kissling GE, Walmer DK, Robboy SJ \& Dixon D 2010 Human uterine leiomyomaderived fibroblasts stimulate uterine leiomyoma cell proliferation and collagen type I production, and activate RTKs and TGF $\beta$ receptor signaling in coculture. Cell Communication and Signaling 810. (doi:10.1186/1478-811X-8-10)

Mote PA, Balleine RL, McGowan EM \& Clarke CL 2000 Heterogeneity of progesterone receptors $\mathrm{A}$ and $\mathrm{B}$ expression in human endometrial glands and stroma. Human Reproduction 15 48-56. (doi:10.1093/humrep/15. suppl_3.48)

Neuville P, Yan Z, Gidlof A, Pepper MS, Hansson GK, Gabbiani G \& Sirsjo A 1999 Retinoic acid regulates arterial smooth muscle cell proliferation and phenotypic features in vivo and in vitro through an RAR $\alpha$-dependent signaling pathway. Arteriosclerosis, Thrombosis, and Vascular Biology 19 1430-1436. (doi:10.1161/01.ATV.19.6.1430)

Noy N 2000 Retinoid-binding proteins: mediators of retinoid action. Biochemical Journal 348 481-495. (doi:10.1042/0264-6021:3480481)

Noy N 2010 Between death and survival: retinoic acid in regulation of apoptosis. Annual Review of Nutrition 30 201-217. (doi:10.1146/ annurev.nutr.28.061807.155509)

Peddada SD, Laughlin SK, Miner K, Guyon J-P, Haneke K, Vahdat HL, Semelka RC, Kowalik A, Armao D, Davis B et al. 2008 Growth of uterine leiomyomata among premenopausal black and white women. PNAS 105 19887-19892. (doi:10.1073/pnas.0808188105)

Polanska UM \& Orimo A 2013 Carcinoma-associated fibroblasts: non-neoplastic tumour-promoting mesenchymal cells. Journal of Cellular Physiology 228 1651-1657. (doi:10.1002/jcp.24347)

Rein MS, Barbieri RL \& Friedman AJ 1995 Progesterone: a critical role in the pathogenesis of uterine myomas. American Journal of Obstetrics and Gynecology 172 14-18. (doi:10.1016/0002-9378(95)90077-2)

Rhinn M \& Dollé P 2012 Retinoic acid signalling during development. Development 139 843-858. (doi:10.1242/dev.065938)

Rice KE, Secrist JR, Woodrow EL, Hallock LM \& Neal JL 2012 Etiology, diagnosis, and management of uterine leiomyomas. Journal of Midwifery \& Women's Health 57 241-247. (doi:10.1111/j.1542-2011.2012.00176.x)

Roth TM, Klett C \& Cowan BD 2007 Expression profile of several genes in human myometrium and uterine leiomyoma. Fertility and Sterility $\mathbf{8 7}$ 635-641. (doi:10.1016/j.fertnstert.2006.10.001)

Sadan O, Vaniddekinge B, Vangelderen CJ, Savage N, Becker PJ, Vanderwalt LA \& Robinson M 1987 Estrogen and progesterone-receptor concentrations in leiomyoma and normal myometrium. Annals of Clinical Biochemistry 24 263-267. (doi:10.1177/000456328702400304)

Schindelin J, Arganda-Carreras I, Frise E, Kaynig V, Longair M, Pietzsch T, Preibisch S, Rueden C, Saalfeld S, Schmid B et al. 2012 Fiji: an open-source platform for biological-image analysis. Nature Methods $\mathbf{9}$ 676-682. (doi:10.1038/nmeth.2019)

Seidel CL 1997 Cellular heterogeneity of the vascular tunica media: implications for vessel wall repair. Arteriosclerosis, Thrombosis, and Vascular Biology 17 1868-1871. (doi:10.1161/01.ATV.17.10.1868)

Shozu M, Murakami K \& Inoue M 2004 Aromatase and leiomyoma of the uterus. Seminars in Reproductive Medicine 22 51-60. (doi:10.1055/s2004-823027)

Shyamala G, Barcellos-Hoff MH, Toft D \& Yang X 1997 In situ localization of progesterone receptors in normal mouse mammary glands: absence of receptors in the connective and adipose stroma and a heterogeneous distribution in the epithelium. Journal of Steroid Biochemistry and Molecular Biology 63 251-259. (doi:10.1016/S0960-0760(97)00128-3)
Skubitz KM \& Skubitz APN 2003 Differential gene expression in uterine leiomyoma. Journal of Laboratory and Clinical Medicine 141 297-308. (doi:10.1016/S0022-2143(03)00007-6)

Snijders MP, de Goeij AF, Debets-Te Baerts MJ, Rousch MJ, Koudstaal J \& Bosman FT 1992 Immunocytochemical analysis of oestrogen receptors and progesterone receptors in the human uterus throughout the menstrual cycle and after the menopause. Journal of Reproduction and Fertility 94 363-371. (doi:10.1530/jrf.0.0940363)

Tang Z, Li Y, Wan P, Li X, Zhao S, Liu B, Fan B, Zhu M, Yu M \& Li K 2007 LongSAGE analysis of skeletal muscle at three prenatal stages in Tongcheng and Landrace pigs. Genome Biology 8 R115. (doi:10.1186/ gb-2007-8-6-r115)

Tanwar PS, Lee HJ, Zhang L, Zukerberg LR, Taketo MM, Rueda BR \& Teixeira JM 2009 Constitutive activation of $\beta$-catenin in uterine stroma and smooth muscle leads to the development of mesenchymal tumors in mice. Biology of Reproduction 81 545-552. (doi:10.1095/biolreprod. 108.075648)

Treloar SA, Do KA, O'Connor VM, O'Connor DT, Yeo MA \& Martin NG 1999 Predictors of hysterectomy: an Australian study. American Journal of Obstetrics and Gynecology 180 945-954. (doi:10.1016/ S0002-9378(99)70666-6)

Tsibris JC, Porter KB, Jazayeri A, Tzimas G, Nau H, Huang H, Kuparadze K, Porter GW, O'Brien WF \& Spellacy WN 1999 Human uterine leiomyomata express higher levels of peroxisome proliferator-activated receptor $\gamma$, retinoid $X$ receptor $\alpha$, and all-trans retinoic acid than myometrium. Cancer Research 59 5737-5744.

Tsibris JC, Segars J, Coppola D, Mane S, Wilbanks GD, O'Brien WF \& Spellacy WN 2002 Insights from gene arrays on the development and growth regulation of uterine leiomyomata. Fertility and Sterility $\mathbf{7 8}$ 114-121. (doi:10.1016/S0015-0282(02)03191-6)

Tuominen VJ, Ruotoistenmaki S, Viitanen A, Jumppanen M \& Isola J 2010 ImmunoRatio: a publicly available web application for quantitative image analysis of estrogen receptor (ER), progesterone receptor (PR), and Ki-67. Breast Cancer Research 12 R56. (doi:10.1186/bcr2615)

Vladic-Stjernholm Y, Vladic T, Blesson C, Ekman-Ordeberg G \& Sahlin L 2009 Prostaglandin treatment is associated with a withdrawal of progesterone and androgen at the receptor level in the uterine cervix. Reproductive Biology and Endocrinology 7 116. (doi:10.1186/14777827-7-116)

Weston G, Trajstman AC, Gargett CE, Manuelpillai U, Vollenhoven BJ \& Rogers PAW 2003 Fibroids display an anti-angiogenic gene expression profile when compared with adjacent myometrium. Molecular Human Reproduction 9 541-549. (doi:10.1093/molehr/gag066)

Yin H, Lo JH, Kim J-Y, Marsh EE, Kim J, Ghosh AK, Bulun S \& Chakravarti D 2013 Expression profiling of nuclear receptors identifies key roles of NR4A subfamily in uterine fibroids. Molecular Endocrinology 27 726-740. (doi:10.1210/me.2012-1305)

Zaitseva M, Vollenhoven BJ \& Rogers PAW 2006 In vitro culture significantly alters gene expression profiles and reduces differences between myometrial and fibroid smooth muscle cells. Molecular Human Reproduction 12 187-207. (doi:10.1093/molehr/gal018)

Zaitseva M, Vollenhoven BJ \& Rogers PAW 2007 Retinoic acid pathway genes show significantly altered expression in uterine fibroids when compared with normal myometrium. Molecular Human Reproduction 13 577-585. (doi:10.1093/molehr/gam040)

Zaitseva M, Holdsworth-Carson SJ, Waldrip L, Nevzorova J, Martelotto L, Vollenhoven BJ \& Rogers PA 2013 Aberrant expression and regulation of NR2F2 and CTNNB1 in uterine fibroids. Reproduction 146 91-102. (doi:10.1530/REP-13-0087)

Zhao D \& Rogers PAW 2013 Is fibroid heterogeneity a significant issue for clinicians and researchers? Reproductive Biomedicine Online 27 64-74. (doi:10.1016/j.rbmo.2013.04.001)

Received 10 November 2013

First decision 6 January 2014

Revised manuscript received 26 January 2014

Accepted 30 January 2014 